\title{
Karakteristik Fungsionalitas dan Mikrostruktur Komposit Aspal-Silika-Karbosil
}

\author{
Lady Permatasari $^{\left(a^{*}\right)}$, Simon Sembiring ${ }^{(b)}$, dan Posman Manurung ${ }^{(c)}$ \\ Jurusan Fisika, Universitas Lampung,Bandar Lampung, Indonesia, 35141 \\ Email :(a*) permatasarilady@yahoo.co.id, ${ }^{(b)}$ simon.sembiring@fmipa.unila.ac.id, \\ ${ }^{(c)}$ reip65@yahoo.com
}

Diterima (07 Desember 2021), Direvisi (29 Januari 2022)

\begin{abstract}
Synthesis and characterization of asphalt have been modified with silica and carbosil composite. This research was conducted to determine the functionality and microstructure of the asphalt-silica-carbosil composite with a weight composition ratio of $0: 50: 50 ; 15: 42.5: 42.5 ; 20: 40: 40 ; 25: 37.5: 37.5 ; 30: 35: 35$; 35:32.5:32.5. Silica is obtained from rice husk using the sol gel method and carbosil was obtained by the pyrolysis method. The results of FTIR analysis obtained that the functional groups formed from each composition variation were $\mathrm{O}-\mathrm{H}, \mathrm{C}-\mathrm{H}, \mathrm{C} \equiv \mathrm{C}, \mathrm{C}=\mathrm{O}, \mathrm{Si}-\mathrm{O}-\mathrm{Si}$, and $\mathrm{Si}-\mathrm{O}$. The results of microstructural analysis showed the presence of lumps scattered on the surface. The composition of the elements formed is dominated by elements of $\mathrm{C}, \mathrm{Si}, \mathrm{O}, \mathrm{N}$, and a little $\mathrm{Na}, \mathrm{K}$ and $\mathrm{S}$. The results of the physical test showed that there were variations in the composition of the sample so the density, absorption, and hardness value decreased.
\end{abstract}

Keywords: asphalt, silica, carbosil, FTIR, and SEM

\begin{abstract}
Abstrak. Telah dilakukan sintesis dan karakterisasi aspal yang dimodifikasi dengan komposit silika dan karbosil. Penelitian ini dilakukan untuk mengetahui fungsionalitas dan mikrostruktur komposit aspal-silikakarbosil dengan perbandingan komposisi berat 0:50:50; 15:42.5:42.5; 20:40:40; 25:37.5:37.5; 30:35:35; 35:32.5:32.5. Silika diperoleh dengan menggunakan metode alkalis dan karbosil diperoleh dengan metode pirolisis. Hasil analisis FTIR diperoleh gugus fungsi yang terbentuk dari setiap variasi komposisi yaitu $\mathrm{O}-\mathrm{H}, \mathrm{C}-$ $\mathrm{H}, \mathrm{C} \equiv \mathrm{C}, \mathrm{C}=\mathrm{O}, \mathrm{Si}-\mathrm{O}-\mathrm{Si}$, dan $\mathrm{Si}-\mathrm{O}$. Hasil analisis mikrostruktur menunjukkan adanya gumpalan yang mengindikasikan sebagai silika-karbosil yang tersebar di permukaan. Komposisi unsur yang terbentuk adalah didominasi unsur $\mathrm{C}, \mathrm{Si}, \mathrm{O}, \mathrm{N}$, dan sedikit $\mathrm{Na}, \mathrm{K}$ dan $\mathrm{S}$. Hasil uji fisis menunjukkan dengan adanya variasi komposisi sampel maka nilai densitas, nilai daya serap air, dan nilai kekerasan menurun.
\end{abstract}

Kata kunci: aspal, silika, karbosil, FTIR, dan SEM

\section{PENDAHULUAN}

Aspal merupakan hasil olahan minyak bumi yang diperoleh secara alami melalui proses distilasi [1]. Aspal berwarna cokelat tua berbentuk semipadat sampai berwarna hitam berbentuk padat [2]. Aspal mengandung komposisi yang terdiri dari karbon (82-88\%), hidrogen (8-11\%), sulfur $(0-6 \%)$, oksigen $(0-1,5 \%)$, dan nitrogen $(0-$ $1 \%$ ) [1]. Aspal pada umumnya digunakan pada perkerasan jalan [3]. Dari hasil pengamatan selama ini penggunaan aspal mengalami keretakan dan kerusakan sebelum waktunya karena suhu dan lalu lintas yang tinggi sehingga mengakibatkan berkurangnya kekuatan aspal dan agregat. Oleh karena itu, perlu dilakukan campuran pada aspal menggunakan berbagai pengubah untuk memodifikasi dan meningkatkan kinerja aspal. Beberapa pengubah yang menjadi objek peneliti adalah bahan komposit seperti silika dan karbosil.

Beberapa bahan nabati yang dapat digunakan sebagai sumber silika antara lain daun bambu [4], rumput gajah [5], tongkol jagung [6] dan sekam padi [7]. Silika sekam padi dapat diperoleh dengan metode alkalis (sol-gel) [8]. Penelitian mengenai ekstraksi silika sekam padi dengan metode alkalis memperoleh kemurnian silika sebesar 98,589 [9]. 
Silika memiliki sifat fisis antara lain densitas 2,2-2,65 g/ $\mathrm{cm}^{3}$, titik didih $2230{ }^{\circ} \mathrm{C}$, titik lebur $1740{ }^{\circ} \mathrm{C}$, berbentuk padat, dan berwarna putih [10]. Sifat kimia silika antara lain tidak larut dalam air, sebagai adsorben, dan tahan terhadap zat kimia. Sehingga silika sekam padi berpotensi sebagai campuran pada aspal dengan memanfaatkannya sebagai bahan pengisi [11].

Selain silika, bahan komposit lain yang dapat digunakan yaitu karbosil. Karbosil adalah material gabungan dari komposit silika dan karbon [12]. Karbosil juga dapat diperoleh dengan bahan dasar sekam padi melalui metode pirolisis [13]. Karbosil memiliki energi absorpsi tinggi 44,4 kJ/mol sehingga berpotensi sebagai absorben [14].

Penelitian terkait komposit aspal telah dilakukan Yao dkk. (2012) dengan menambahkan nanosilika pada aspal menunjukkan hasil bahwa partikel nanosilika tersebar dengan baik dalam matriks aspal dan tersebarnya nanosilika dapat memperbaiki modulus campuran aspal hingga meningkatkan ketahanan aspal terhadap keretakan suhu tinggi [15].

Berdasarkan uraian di atas, peneliti tertarik untuk melakukan modifikasi aspal berbahan komposit silika dan karbosil dari sekam padi, untuk mengetahui karakteristik gugus fungsi, mikrostruktur, densitas, daya serap air, dan kekerasan komposit aspalsilika-karbosil.

\section{METODE PENELITIAN}

\section{Alat dan Bahan}

Alat-alat yang digunakan pada penelitian ini adalah alat pirolisis, hydraulic press, beaker glass, gelas ukur, neraca digital, alumunium foil, $\mathrm{pH}$ indikator, kompor listrik, spatula, mortar dan alu, corong buchner, hot plate stirrer, stopwatch, kertas saring, oven, pengayak (mes) nomor 200, stainless steel bowl, dan botol sampel. Adapun bahan-bahan yang digunakan dalam penelitian ini adalah sekam padi,
$\mathrm{NaOH} 1,5 \%, \mathrm{HNO}_{3} 10 \%$, akuades, bensin, serta aspal sebagai bahan pengikat.

\section{Metode Penelitian}

Sekam padi yang telah bersih ditimbang sebanyak 50 gram dimasukkan ke dalam beaker glass. Berikutnya penambahan larutan $\mathrm{NaOH} 1,5 \%$ dipanaskan selama 30 menit kemudian ditutup dengan alumunium foil dan didiamkan selama 24 jam. Diperoleh filtrat sol silika hasil penyaringan menggunakan corong buchner. Sol silika ditetesi larutan $\mathrm{HNO}_{3} 10 \%$ hingga $\mathrm{pH} 7$ dan terbentuk gel. Gel dikalsinasi pada suhu $110{ }^{\circ} \mathrm{C}$ selama 4 jam hingga diperoleh silika padatan. Silika padatan dihaluskan dan diayak menggunakan mes nomor 200 diperoleh silika serbuk berwarna putih. Sementara, karbosil berwarna hitam diperoleh dari proses pembakaran sekam padi pada suhu $450{ }^{\circ} \mathrm{C}$ selama 6 jam.

Paduan aspal-silika-karbosil dilakukan dengan mencairkan aspal, ditambahkan serbuk silika dan serbuk karbosil dipanaskan hingga tercampur merata. Berikutnya dilakukan pemanasan pada suhu $100{ }^{\circ} \mathrm{C}$ selama 4 jam. Paduan aspal-silika-karbosil dihaluskan dan diayak menggunakan ayakan mes nomor 200. Selanjutnya, serbuk paduan aspal-silika-karbosil dibentuk menjadi pelet menggunakan alat hydrolic press.

\section{HASIL DAN PEMBAHASAN}

\section{Hasil Karakterisasi FTIR}

Hasil analisis spektrum FTIR sampel komposit aspal-silika-karbosil dengan perbedaan komposisi dapat dilihat pada Gambar 1(a-f). Pada Gambar 1(a) merupakan spektrum FTIR sampel silika dan karbosil tanpa aspal dan Gambar 1(b-f) merupakan spektrum FTIR sampel komposit aspal-silika-karbosil dengan komposisi yang berbeda-beda. Pada Gambar 1(a) menunjukkan bahwa pada puncak serapan 
dengan bilangan gelombang $3746 \mathrm{~cm}^{-1}$ mengindikasikan gugus hidroksil $(\mathrm{O}-\mathrm{H})$, didukung munculnya bilangan gelombang $3615 \mathrm{~cm}^{-1}$. Keberadaan gugus hidroksil $(\mathrm{O}-\mathrm{H})$ telah terjadi penyerapan molekul air pada silika (Si) yang teroksidasi membentuk gugus silanol (Si$\mathrm{OH})$ [16].

Berikutnya terdapat vibrasi ulur pada bilangan gelombang $2306 \mathrm{~cm}^{-1}$ mengindikasikan kehadiran gugus fungsi $(\mathrm{C} \equiv \mathrm{C}) . \quad$ Kehadiran gugus $(\mathrm{C} \equiv \mathrm{C})$ didukung dengan munculnya bilangan gelombang $2066 \mathrm{~cm}^{-1}$. Keberadaan gugus fungsi $(\mathrm{C} \equiv \mathrm{C})$ mengindikasikan terjadi proses karbonisasi dari pembakaran bahan organik sekam padi menghasilkan unsur karbon [17].

Kemudian, kehadiran gugus karbonil $(\mathrm{C}=\mathrm{O})$ pada puncak serapan dengan bilangan gelombang $1610 \mathrm{~cm}^{-1}$ didukung adanya bilangan gelombang $1541 \mathrm{~cm}^{-1}$ yang mengindikasikan terjadi proses karbonisasi dari pembakaran sekam padi menghasilkan unsur karbon. Maka, kehadiran gugus fungsi $(\mathrm{C} \equiv \mathrm{C})$ dan gugus fungsi $(\mathrm{C}=\mathrm{O})$ menandakan komponen organik sekam padi terkarbonisasi menjadi unsur karbon yang kemudian tersimpan di dalam pori-pori silika menghasilkan komposit silika karbon yang dikenal dengan karbosil [12].

Pada bilangan gelombang $1059 \mathrm{~cm}^{-1}$ mengindikasikan adanya vibrasi ulur gugus siloksan ( $\mathrm{Si}-\mathrm{O}-\mathrm{Si}$ ) [9]. Kehadiran gugus siloksan (Si-O-Si) didukung adanya vibrasi ulur pada bilangan gelombang $796 \mathrm{~cm}^{-1}$ mengindikasikan adanya gugus fungsi siloksi ( $\mathrm{Si}-\mathrm{O})$ [18]. Berdasarkan Gambar 1(a-f), puncak serapan yang terkait dengan sampel (a) yang juga muncul pada sampel (b-f) yaitu pada bilangan gelombang 3746, 3615, 2200, 1610, dan $1448 \mathrm{~cm}^{-1}$.

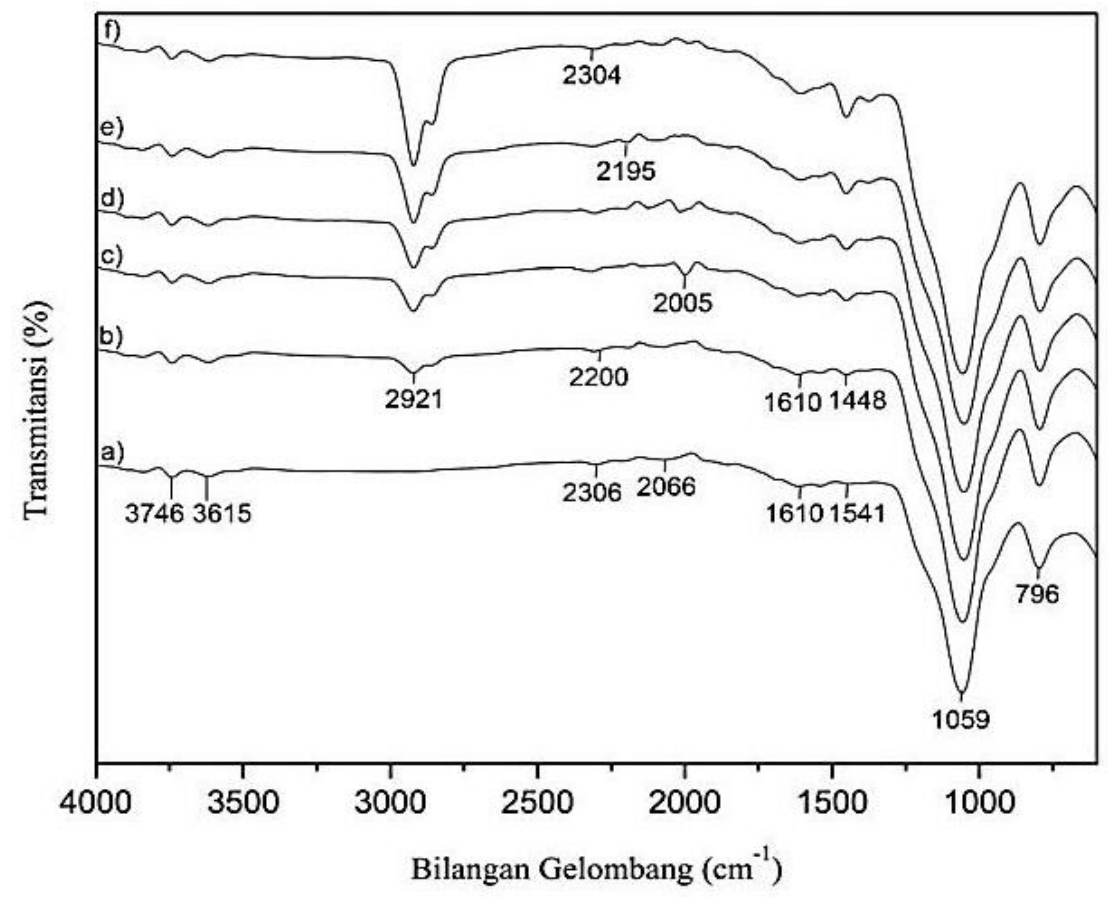

Gambar 1. Spektrum FTIR sampel aspal-silika-karbosil dengan perbandingan (a)0:50:50; (b) $15: 42,5: 42,5$; (c)20:40:40; (d)25:37,5:37,5; (e)30:35:35; dan (f)35:32,5:32,5 
Tabel 1. Puncak serapan gugus fungsi aspal-silika-karbosil dengan perbandingan (a) 0:50:50; (b) $15: 42,5: 42,5$; (c) $20: 40: 40$; (d) $25: 37,5: 37,5$; (e) $30: 35: 35$; dan (f) $35: 32,5: 32,5$

\begin{tabular}{|c|c|c|c|c|c|c|}
\hline \multirow{2}{*}{$\begin{array}{c}\text { Gugus } \\
\text { Fungsi }\end{array}$} & \multicolumn{6}{|c|}{ Bilangan Gelombang pada Sampel $\left(\mathrm{cm}^{-1}\right)$} \\
\hline & $\begin{array}{c}\text { (a) } \\
0: 50: 50\end{array}$ & $\begin{array}{c}\text { (b) } \\
15: 42,5: 42,5\end{array}$ & $\begin{array}{c}\text { (c) } \\
20: 40: 40\end{array}$ & $\begin{array}{c}\text { (d) } \\
25: 37,5: 37,5\end{array}$ & $\begin{array}{c}\text { (e) } \\
30: 35: 35\end{array}$ & $\begin{array}{c}\text { (f) } \\
35: 32,5: 32,5\end{array}$ \\
\hline $\mathrm{O}-\mathrm{H}$ & 3746 & 3745 & 3745 & 3745 & 3745 & 3745 \\
\hline $\mathrm{O}-\mathrm{H}$ & 3615 & 3615 & 3615 & 3615 & 3615 & 3615 \\
\hline $\mathrm{C}-\mathrm{H}$ & - & 2921 & 2921 & 2922 & 2922 & 2922 \\
\hline $\mathrm{C} \equiv \mathrm{C}$ & 2306 & 2200 & 2005 & 2013 & 2195 & 2304 \\
\hline $\mathrm{C}=\mathrm{O}$ & 1610 & 1610 & 1610 & 1610 & 1610 & 1610 \\
\hline $\mathrm{C}-\mathrm{H}$ & - & 1448 & 1448 & 1448 & 1449 & 1453 \\
\hline $\mathrm{Si}-\mathrm{O}-\mathrm{Si}$ & 1059 & 1059 & 1056 & 1056 & 1055 & 1055 \\
\hline Si-O & 796 & 796 & 795 & 795 & 793 & 793 \\
\hline
\end{tabular}

Berdasarkan Gambar 1(b-f) terlihat bahwa dengan adanya penambahan komposisi aspal mengakibatkan terjadinya pergeseran puncak serapan. Pergeseran puncak serapan karena adanya interaksi yang kuat antara gugus fungsi silikakarbosil dengan aspal yang dipengaruhi oleh struktur molekul dan penambahan komposisi aspal [19].

\section{Hasil Karakterisasi SEM-EDS}

Hasil analisis SEM-EDS menampilkan mikrostruktur meliputi topografi, morfologi, dan komposisi unsur yang terkandung dalam sampel. Gambar 2(a) sampel tanpa aspal-silika-karbosil hasil topografi memperlihatkan adanya gumpalan yang tidak seragam dengan distribusi tidak merata di permukaan dan terdapat retakan. Berdasarkan penelitian Kasinathan dkk. (2010) menyatakan bahwa gumpalan yang tidak beraturan menandakan sebagai partikel silika [20].

Hasil morfologi menunjukkan adanya warna gelap sebagai unsur karbon bernomor atom rendah, dan warna terang mengindikasikan unsur silika bernomor atom tinggi [21]. Hasil EDS menunjukkan unsur $\mathrm{C}, \mathrm{Si}, \mathrm{O}$, dan sedikit $\mathrm{N}$ dan Na. Sementara, dengan adanya penambahan komposisi aspal menunjukkan adanya perubahan mikrostruktur pada sampel aspal-silika-karbosil (b-f). Pada
Gambar 2(b) memperlihatkan adanya gumpalan membesar dan retakan semakin sedikit. Berdasarkan Yao dkk. (2012) menyatakan bahwa gumpalan yang terbentuk berupa partikel silika tersebar dengan baik menutupi matriks aspal [15]. Pada Gambar 2(c) dan Gambar 2(d) menunjukkan adanya gumpalan semakin meningkat dan retakan semakin samar. Pada Gambar 2(e) dan Gambar 2(f) menunjukkan adanya gumpalan melebar besar tersebar di permukaan serta tidak ada retakan.

Berdasarkan Gambar 2(b-f) terlihat bahwa dengan penambahan komposisi aspal mengindikasikan adanya gumpalan partikel silika-karbosil tersebar semakin lebar menutupi aspal [15]. Kandungan unsurunsur pada sampel yang lain dapat dilihat pada Tabel 2. Berdasarkan komposisi unsur penyusun sampel komposit aspal-silikakarbosil menunjukkan adanya pengaruh penambahan komposisi aspal yakni terjadi perubahan kandungan silika dan kandungan karbon pada masing-masing sampel. 

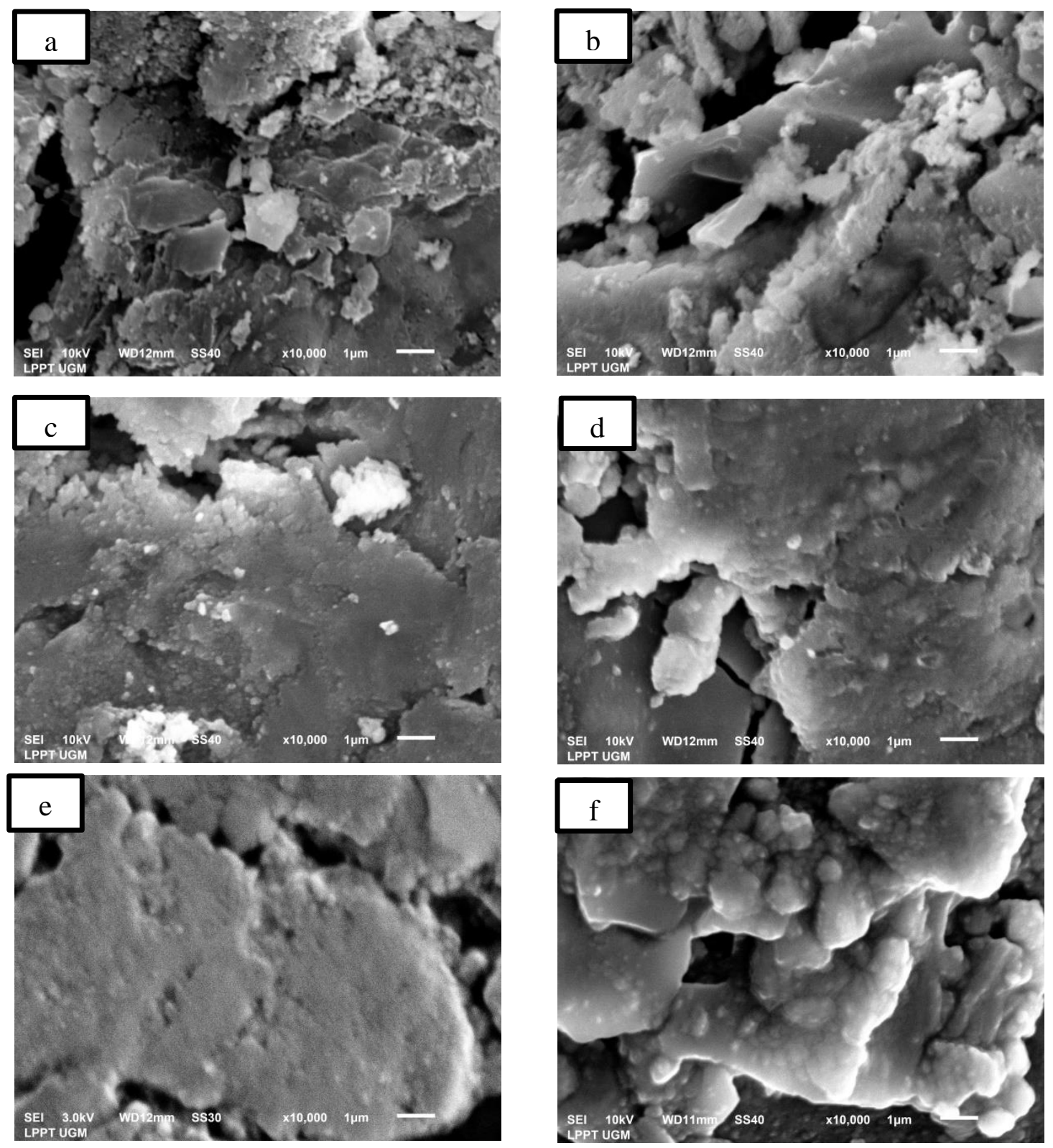

Gambar 2. Hasil SEM dengan perbandingan (a) 0:50:50; (b) 15:42,5:42,5; (c) 20:40:40; (d) $25: 37,5: 37,5 ;$ (e) $30: 35: 35$; dan (f) $35: 32,5: 32,5$

\section{Hasil Densitas}

Hasil analisis uji densitas pada sampel komposit aspal-silika-karbosil dengan perbandingan berbeda ditunjukkan pada Gambar 3. Pada sampel (a) tanpa aspalsilika-karbosil menghasilkan nilai densitas sebesar 4,113 $\mathrm{g} / \mathrm{cm}^{3}$. Sementara, pada sampel (b-f) dengan pengaruh penambahan komposisi aspal menghasilkan nilai densitas yang semakin meningkat. Pada sampel (b) menghasilkan nilai densitas sebesar 3,786 $\mathrm{g} / \mathrm{cm}^{3}$, sampel (c) nilai densitas sebesar $3,441 \mathrm{~g} / \mathrm{cm}^{3}$, sampel (d) sebesar 3,174 $\mathrm{g} / \mathrm{cm}^{3}$, sampel (e) sebesar $2,637 \mathrm{~g} / \mathrm{cm}^{3}$, dan sampel (f) sebesar 2,074 $\mathrm{g} / \mathrm{cm}^{3}$. Penurunan nilai densitas karena telah terjadi proses pemadatan yang memungkinkan adanya perubahan 
Tabel 2. Komposisi penyusun sampel aspal-silika-karbosil

\begin{tabular}{ccccccc}
\hline \multirow{2}{*}{$\begin{array}{c}\text { Unsur } \\
(\%)\end{array}$} & $\mathbf{( a )}$ & $\mathbf{( b )}$ & $\mathbf{( c )}$ & $\mathbf{( d )}$ & $\mathbf{( e )}$ & $\mathbf{( f )}$ \\
\cline { 2 - 7 } & $\mathbf{0 : 5 0 : 5 0}$ & $\mathbf{1 5 : 4 2 , 5 : 4 2 , 5}$ & $\mathbf{2 0 : 4 0 : 4 0}$ & $\mathbf{2 5 : 3 7 , 5 : 3 7 , 5}$ & $\mathbf{3 0 : 3 5 : 3 5}$ & $\mathbf{3 5 : 3 2 , 5 : 3 2 , 5}$ \\
\hline $\mathrm{C}$ & 29,61 & 38,90 & 42,42 & 42,81 & 45,11 & 46,31 \\
$\mathrm{Si}$ & 18,53 & 12,81 & 12,91 & 18,96 & 13,70 & 17,11 \\
$\mathrm{O}$ & 44,35 & 38,25 & 33,77 & 28,00 & 30,66 & 25,98 \\
$\mathrm{~N}$ & 7,06 & 9,63 & 10,63 & 9,31 & 10,07 & 9,33 \\
$\mathrm{Na}$ & 0,45 & 0,41 & 0,27 & 0,45 & 0,46 & 0,56 \\
$\mathrm{~K}$ & - & - & - & 0,47 & - & - \\
$\mathrm{S}$ & - & - & - & - & - & 0,71 \\
\hline
\end{tabular}

mikrostruktur yakni ukuran partikel menjadi lebih besar kemungkinan ukuran partikel besar menutupi permukaan sampel. Sehingga jumlah pori berkurang dan mengakibatkan porositas menurun [22].

\section{Hasil Daya Serap Air}

Hasil analisis uji daya serap air ditunjukkan pada Gambar 4 yang menunjukkan bahwa nilai daya serap air semakin menurun karena dipengaruhi oleh sifat dari aspal sebagai pengikat dan silikakarbosil sebagai agregat [23]. Maka, pada penelitian ini terdapat perbedaan yang signifikan yakni pada sampel tanpa aspalsilika-karbosil dengan perbandingan 0:50:50 Gambar 4(a) menunjukkan nilai daya serap air paling besar yakni 37,28\% yang mengindikasikan silika dan karbosil bersifat hidrofilik sehingga dapat berikatan dengan molekul air.

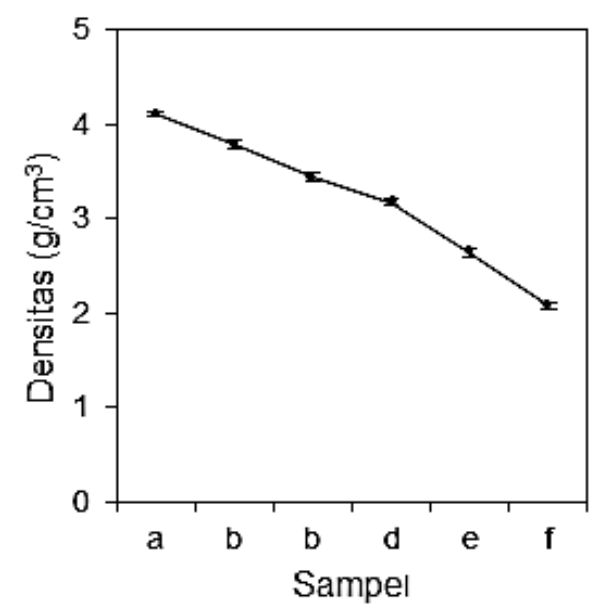

Gambar 3. Hasil Densitas
Sementara, pada sampel aspal-silikakarbosil Gambar 4(b-f) memiliki nilai daya serap air yang semakin menurun yakni sampel (b) nilai daya serap air sebesar 2,30 $\%$, sampel (c) sebesar 1,12\%, sampel (d) sebesar $0,75 \%$, sampel (e) sebesar 0,38 \%, dan sampel (f) sebesar $0,18 \%$. Penurunan nilai daya serap air mengindikasikan adanya pengaruh penambahan aspal yang bersifat hidrofobik sehingga aspal sukar berikatan dengan molekul air. Nilai daya serap air yang kecil mengakibatkan poripori di permukaan semakin sedikit dan rapat. Sehingga dapat dinyatakan bahwa semakin besar nilai densitas (kerapatan) maka semakin kecil nilai daya serapnya terhadap air [23].

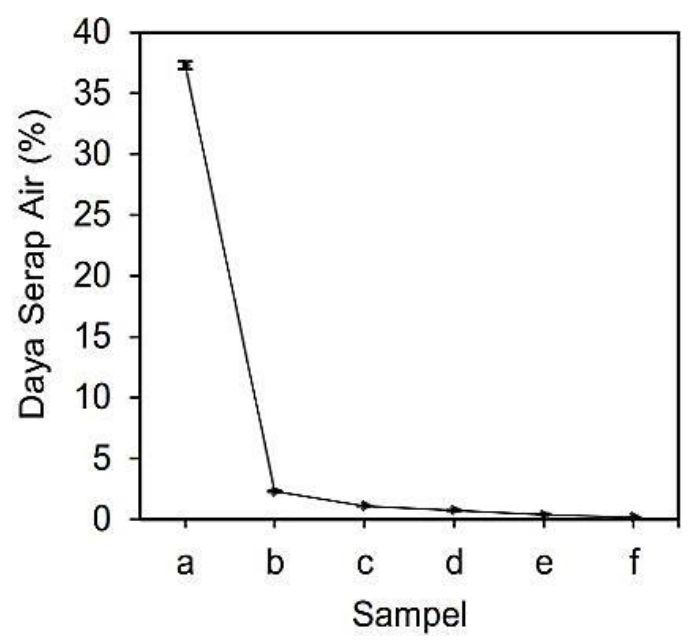

Gambar 4. Hasil daya serap air 


\section{Hasil Kekerasan Vicker}

Hasil uji kekerasan vicker untuk mengetahui sifat mekanik yang memiliki kaitan dengan densitas dan daya serap air disajikan pada Gambar 5. Hasil uji kekerasan vicker pada sampel (a) tanpa aspal-silika-karbosil perbandingan 0:50:50 menunjukkan nilai kekerasan sebesar 1,678 GPa.

Sementara, dengan adanya penambahan komposisi aspal mengindikasikan sampel mengalami penurunan nilai kekerasan seperti pada sampel (b) menunjukkan nilai kekerasan sebesar 1,482 GPa. Pada sampel (c) menunjukkan nilai kekerasan sebesar 1,304 GPa, berikutnya pada sampel (d) menunjukkan nilai kekerasan sebesar 1,221 GPa, selanjutnya sampel (e) menunjukkan nilai kekerasan sebesar 1,160 GPa dan pada sampel (f) nilai kekerasan sebesar 1,027 GPa yang semakin menurun.

Penurunan nilai kekerasan ini mengindikasikan aspal yang ditambahkan tidak mampu mengikat silika-karbosil sehingga pori-pori pada silika-karbosil tidak tertutup menyeluruh. Berdasarkan teoretis (Li dan Ren., 2011) menyatakan bahwa semakin besar densitas (kerapatan) maka semakin kecil porositas, dan semakin rendah kekerasan dengan demikian penyerapan air jadi lebih kuat [23].

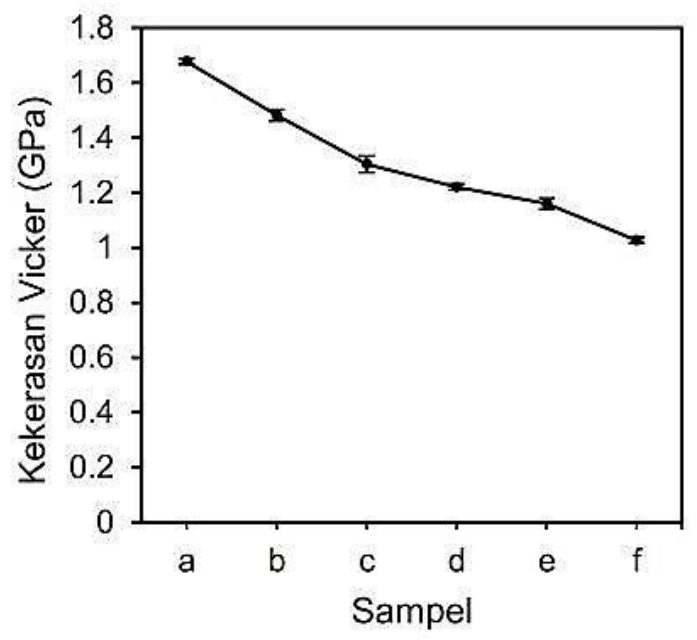

Gambar 5. Hasil kekerasan vicker

\section{KESIMPULAN}

Berdasarkan hasil penelitian maka dapat disimpulkan bahwa pada sampel komposit aspal-silika-karbosil gugus fungsi yang terbentuk adalah $\mathrm{O}-\mathrm{H}, \mathrm{C}-\mathrm{H}, \mathrm{C} \equiv \mathrm{C}, \mathrm{C}=\mathrm{O}$, Si$\mathrm{O}-\mathrm{Si}$ dan Si-O. Hasil analisis SEM-EDS menyatakan bahwa adanya gumpulan yang semakin besar tersebar di permukaan. Gumpalan besar mengindikasikan bahwa telah terjadi penyebaran partikel silika dan karbosil di permukaan aspal. Komposisi unsur yang terbentuk pada sampel komposit aspal-silika-karbosil adalah didominasi unsur $\mathrm{C}, \mathrm{Si}, \mathrm{O}, \mathrm{N}$, dan sedikit $\mathrm{Na}, \mathrm{K}$ dan $\mathrm{S}$. Penambahan kandungan aspal pada sampel menyebabkan nilai densitas menurun yang mengakibatkan nilai kekerasan dan nilai daya serap terhadap air menurun karena pori-pori silika-karbosil telah tertutupi oleh aspal sehingga penyerapan air semakin berkurang.

\section{DAFTAR PUSTAKA}

[1] John Read and David Whiteoak, "Shell Bitumen Handbook." 2003.

[2] E. Gasthauer and M. Maze, "Characterization of Asphalt Fume Composition by GC / MS and Effect of Temperature," vol. 87, pp. 14281434, 2008.

[3] L. Loebera, G. Muller, J. Morel, O. C. Sutton, L. Havre, and L. Havre, "Bitumen in colloid science: a chemical, structural and rheological approach," vol. 77 , no. 13, pp. 14431450, 1998.

[4] N. Noverliana, "Sintesis Keramik Silika dari Daun Bambu dengan Teknik Sol- Gel dan Karakterisasi pada Suhu Kalsinasi 500 O C ," vol. 03, no. 01, pp. 17-23, 2015. 
[5] A. T. L. U. I. Vansyah, "Pemanfaatan Rumput Gajah Sebagai Sumber Silika Untuk Sintesis Zeolit T," vol. 4, no. 2, pp. 51-60, 2017.

[6] G. A. P. K. Wardhani, "Karakterisasi Silika Pada Tongkol Jagung dengan Spektroskopi Infra Merah dan Difraksi Sinar-X," vol. 2, no. 1, pp. 37-42, 2017.

[7] N. Yalc and V. Sevinc, "Studies on silica obtained from rice husk," vol. 27, pp. 219-224, 2001.

[8] C. Jeffrey Brinker and George W. Scherer,"Sol_Gel_Science_the_Phys ics and Chemistry." 1990.

[9] J. A. Bonacin, R. R. Passos, and L. A. Pocrifka, "Rice Husk Reuse in the Preparation of $\mathrm{SnO} 2 / \mathrm{SiO} 2$ Nanocomposite," vol. 18, no. 3, pp. 639-643, 2015.

[10] B. S. Todkar, O. A. Deorukhkar, and S. M. Deshmukh, "Extraction of Silica from Rice Husk," vol. 12, no. 3, pp. 69-74, 2016.

[11] M. Enieb and A. Diab, "ScienceDirect Characteristics of asphalt binder and mixture containing nanosilica," Int. $J$. Pavement Res. Technol., 2017.

[12] P. Valle-Vigón, M. Sevilla, and A. B. Fuertes, "Carboxyl-functionalized mesoporous silica-carbon composites as highly efficient adsorbents in liquid phase," vol. 176, pp. 78-85, 2013.

[13] W. Simanjuntak, S. Sembiring, and K. Sebayang, "Effect of pyrolysis temperatures on composition and electrical conductivity of carbosil prepared from rice husk," Indones. $J$. Chem., vol. 12, no. 2, pp. 119-125, 2012.

[14] A. Gieraka, F. Czechowskib, and R. Leboda, "Improvement of carbonsilica sorbent ( carbosil ) surface properties upon steam activation at 1073 K,” vol. 36, pp. 264-270, 1994

[15] Z. You, D. Ph, and P. E. C. Author, "Properties and Chemical Bonding of Asphalt and Asphalt Mixtures Modified with Nanosilica," pp. 1-16, 2012.

[16] U. Kalapathy, A. Proctor, and J. Shultz, "A simple method for production of pure silica from rice hull ash," Fuel Energy Abstr., vol. 42, no. 1, p. 45, 2001.

[17] N. Claoston, "Waste Management \& Research," 2014.

[18] R. Abu, R. Yahya, and S. Neon, "Production of High Purity Amorphous Silica from Rice Husk," pp. 189-195, 2016.

[19] C. Ouyang, S. Wang, Y. Zhang, and Y. Zhang, "Silica Compound Modified Asphalts with HighTemperature Storage Stability," 2005.

[20] A. Kasinathan, R. Rama, and G. Sivakumar, "Extraction Synthesis and Characterization of Nanosilica from Rice Husk Ash,” 2010.

[21] A. V Gira, G. Caputo, M. C. Ferro, and C. Outline, "Application of Scanning Electron Microscopy e Energy Dispersive X-Ray Spectroscopy," vol. 75, 2017. 
[22] S. Sembiring, "Structural Characterisation of Asphalt-Rice Husk Silica Composites," Ceram. Silikaty, vol. 65, no. 3, pp. 1-9, 2021.

[23] Yan Li and Shuxia Ren, Building Decorative Materials-Woodhead Publishing In Materials. 2011. 
Lady Permatasari: Karakteristik Fungsionalitas dan Mikrostruktur Komposit Aspal-Silika-Karbosil 